\title{
FROM FARM TO TOWN: THE CHANGING PATTERN OF TEXTILE PRODUCTION IN ANGLO-SAXON ENGLAND
}

\begin{abstract}
Through much of the Anglo-Saxon period (the $5^{\text {th }}$ to $11^{\text {th }}$ centuries AD), textile production was a farm-based, rural industry. The middle period, however, saw the appearance of some large estate centres, producing high quality goods for an elite group, and small overseas trading centres through which surplus cloths may have been channelled. As towns began to emerge in the $9^{\text {th }}$ century, opportunities for regional and overseas trade increased. Textile production in Late Anglo-Saxon towns can be seen as a phase of social and economic change, as a supply network for raw materials was established. By this means, foundations were laid for both urban gilds and the English cloth export trade of later centuries.
\end{abstract}

Keywords: textiles, cloth industry, Anglo-Saxon, farm, town, loom, trade

Anglo-Saxon England is a particularly profitable field for the investigation of the dynamics and organisation of textile production, because it represents a place and a time that saw significant economic, political, cultural, social and religious change. Characterising the ways in which the textile industry adapted to meet these changes can be as instructive to the social and economic historian as it is to those focused primarily on textiles.

The region in question roughly equates to modern England and the time-span covered is the $5^{\text {th }}$ to $11^{\text {th }}$ centuries AD. There are many complexities within this field of research, but, broadly speaking, during this time the country evolved from a landscape of small self-sufficient farming units, through larger estates controlled by an aristocracy, to an agricultural system that could support an urban population. Social organisation shifted from an essentially tribal structure, through the establishment of regional dynastic rulers, to a ranked social hierarchy within a (mostly) unified kingdom. The first two centuries also witnessed immigration from across the North Sea, and then, from the $9^{\text {th }}$ century onwards, an influx from Scandinavia and its colonies into northern parts of England. Trade at first mostly relied on local exchange, until small overseas trading centres began to emerge, followed by towns with far-reaching international connections. The period also saw conversion of

* The Anglo-Saxon Laboratory, York; (D https://orcid.org/00000002-7845-7524; pwr@aslab.co.uk the population from Paganism to Christianity and the rise of the Church as a powerful political entity and consumer of valuable goods. The textile crafts can be shown to hold a mirror to each of these transitions.

The full range of textile crafts, from fibre collection and processing, through dyeing, spinning and weaving, to cloth finishing, garment-making and laundering are represented in the archaeological evidence. Surviving textiles also indicate the nature of the cloth produced. Weaving and dyeing, however, will be given especial emphasis in this paper, because, in this particular context, they give the strongest data on economic and social aspects of textile production.

The $5^{\text {th }}$ and $6^{\text {th }}$ centuries: cloth production on the farm

The province of Britannia lay at the far north-west corner of the Roman Empire. When the economic and political strains of the $3^{\text {rd }}$ and $4^{\text {th }}$ centuries led to the withdrawal of Roman rule and military support, the Romano-British found themselves faced with a collapse in their established way of life. Specialist industries and trade networks declined, and people began to desert the towns that had been the hubs of civic and commercial life. ${ }^{1}$ Onto this scene came waves of predominantly Germanic immigrants from across the North Sea, reaching into eastern and southern parts of the country. The numbers and status of the incomers has been debated, but their influence was significant enough to introduce

\footnotetext{
${ }^{1}$ Higham 1992, 69-86.
} 


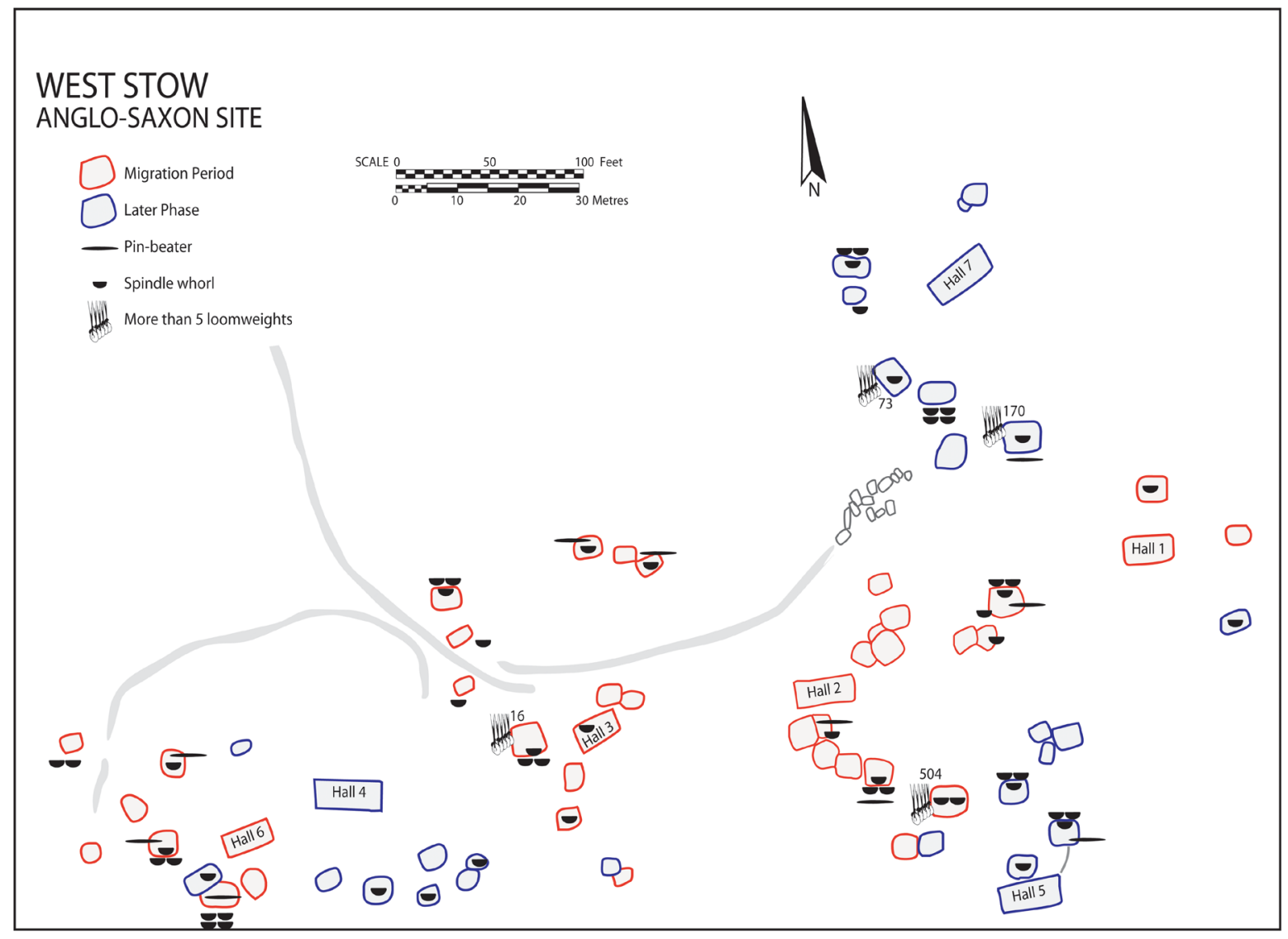

Fig. 1. Textile equipment at West Stow Early Anglo-Saxon village, Suffolk. Plan of the excavated features, showing the main halls, smaller outbuildings and the distribution of spinning and weaving equipment. 'Migration period' indicates the $5^{\text {th }}$ and $6^{\text {th }}$ centuries up to AD c. 570; and 'Late Phase' in this context means the later $6^{\text {th }}$ and $7^{\text {th }}$ centuries. Note the absence of any equipment from the main halls. Derived from plans and data in West 1985. (C) The Anglo-Saxon Laboratory.

a new language, the basis of the English spoken today, ${ }^{2}$ and to leave an identifiable mark in the genetics of the modern population. ${ }^{3}$

By the mid- $5^{\text {th }}$ century, much of the population was living in farmsteads, hamlets or villages, dotted about the landscape. One study of the location of sites in Norfolk has shown that settlements were frequently situated close to boundaries between different soil types, which would have allowed mixed farming and access to land suitable for foraging and hunting. ${ }^{4}$ The typical farm complex of this period consisted of a main post-built structure, or 'hall' with a number of ancillary buildings set at a distance from the hall ${ }^{5}$ (Fig. 1). These outbuildings (most commonly the structures known as 'pit-huts', 'sunken-featured buildings' or Grubenhäuser) measured from $3 \times 2$ metres to $5 \times 4$ metres in plan and appear to have been used for craft-working and storage. The full chain of textile crafts has left remains in and around the settlement, ${ }^{6}$

\footnotetext{
${ }^{2}$ Hills 2003, 41-55.

${ }^{3}$ Leslie et al. 2015, 313.

${ }^{4}$ Chester-Kadwell 2009, 121-127.

${ }^{5}$ Tipper 2004, 4-25.

${ }^{6}$ Walton Rogers 2007a, 9-47.
}

but it is in the largest of the outbuildings that we find most evidence for the manufacture and storage of loom weights, and for weaving. ${ }^{7}$ The frequency with which textile equipment is discovered in settlements of the period, and the range and variety at each site, strongly suggests that each farm was taking responsibility for the production of its own cloth.

Within agrarian societies of this sort, it is possible to predict how the production of textiles is likely to have fitted into the cycle of the year. Sheep, which were kept for milk and mutton as much as wool, ${ }^{8}$ would be sheared in early summer and their fleeces taken back to the farmstead for sorting, cleaning and spinning. Flax would be sown in early spring and harvested in summer, while hemp, which has a short growing season, could be sown later, into land left empty by early crops. The preliminary processing of the plants (rippling and retting) would be done outside the settlement, but such evidence as exists indicates that the final processing (pounding, scutching and heckling) was conducted within the area of the farmstead, probably in autumn, in the open

\footnotetext{
${ }^{7}$ Tipper 2004, 164-182.

${ }^{8}$ Crabtree 1990, 50-51, 83-84.
} 


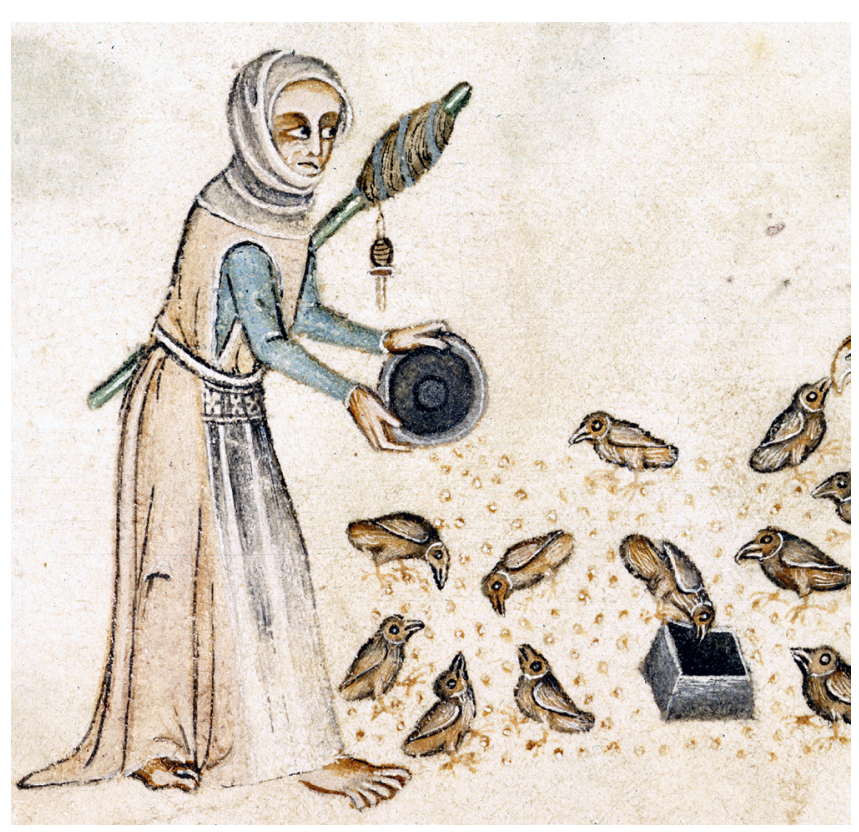

Fig. 2. Woman feeding poultry while carrying her spinning equipment. Luttrell Psalter, English, 1320-1340. British Library Additional Manuscript 4213, fol. 166v. (C) British Library Board.

air and away from buildings. ${ }^{9}$ The spinning of the prepared fibres could then be fitted around other tasks. Spindle whorls tend to have a wide distribution in settlements, in and around the buildings, which probably reflects the practice we see in later manuscript illustrations, where women carried their spinning equipment with them while they went about their daily chores (Fig. 2). The location of spindle whorls therefore reflects the paths of women's daily lives, rather than a specific zone of textile production.

Dyes were probably applied to raw wool or spun yarn, since dyeing a whole cloth is a cumbersome procedure, best achieved with specialist equipment. No dye-pots have been recovered from the early period, but the dyestuffs identified by analysis so far have proved to be primarily materials that could be collected in the wild. ${ }^{10}$ They include bedstraw ( $\mathrm{Ga}$ lium verum L.) for shades of red, lichens for purple, weld (Reseda luteola L.) or greenweed (Genista tinctoria L.) for yellow, and nuts, barks and galls for browns and blacks. Woad (Isatis tinctoria L.) for blue is the only cultivated plant to have been detected so far in the standard textile types. Indeed, dyes have been mostly detected in small items such as head-coverings, bags and tablet-woven bands, and natural fleece colours, brown, black and grey, were often used in full-size cloths.

The main weaving equipment in the early farmsteads was the warp-weighted loom (Fig. 3). This is represented by circular clay loom weights, which are recovered in considerable numbers from settlements, and by cigar-shaped bone and antler pin-beaters and iron weaving battens found in both

\footnotetext{
${ }^{9}$ Walton Rogers 2007a, 17-21, 41.

${ }^{10}$ Walton Rogers 2007a, 37-38, 62-64, 73-74.
}

occupation sites and women's graves. The balanced weave structures of most surviving textiles, namely tabby (plain weave) and 2/2 twill, are typical products of this loom. The loom weights usually weighed 150-550 $\mathrm{g}$ and at Mucking, Essex, there were two main groups, one with a peak around 200-300 g and the other 400-450 g, ${ }^{11}$ which may represent linen and wool respectively. In some instances, loom weights could have been dumped in the hut at the end of the building's life. There are other cases, however, where the structure has burned down or been abandoned with a working loom in situ, and in some of these huts there appears to have been one set of weights in use on the loom and a second set stored on sticks nearby. ${ }^{12}$ From the distribution of finds within sites, it seems likely that one, or at most two, of the ancillary huts were used for weaving at any one time within each farmstead complex.

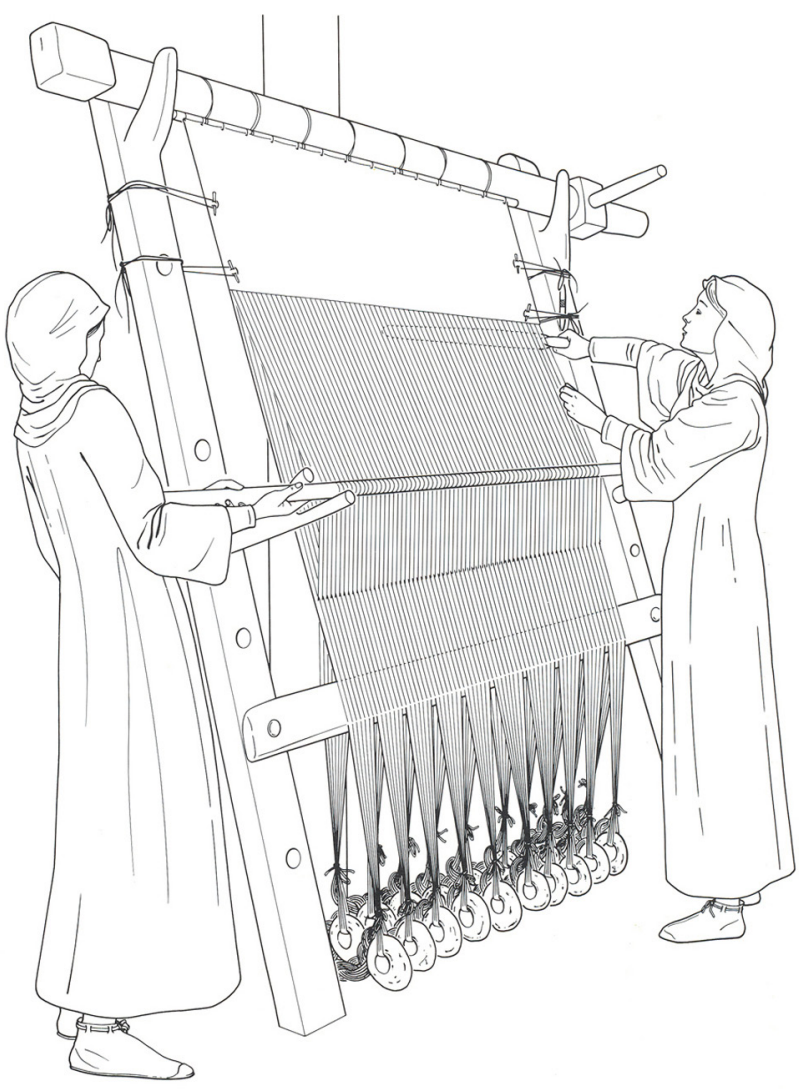

Fig 3. The warp-weighted loom. Drawing Simon Chew, YAT. (C) The Anglo-Saxon Laboratory.

It has been established that women were in charge of this task, since they were buried with their textile equipment and their skills and responsibilities are alluded to in later written sources. ${ }^{13}$ It is also clear that it was a well-respected

\footnotetext{
${ }^{11}$ Hamerow 1993, 66-68.

${ }^{12}$ Tipper 2004, 168-169; Walton Rogers 2007a, 30-32, 44-45.

${ }^{13}$ Walton Rogers 2014a.
} 
craft. The iron weft-beaters used to beat up the weft tend to be found in the graves of women furnished with valuable brooches, necklaces and other accessories. These were obviously not servants or slaves and it can be argued that they represent the senior woman in the household, perhaps best described as the 'farm matron'. A parallel can be drawn with women of comparable status in Scandinavia, who are regarded as having had economic and legal power, derived from their position in charge of the indoor tasks of the household. ${ }^{14}$

The textiles recovered from the cemeteries, where clothed and furnished burial was practised until the late $7^{\text {th }}$ century, reveal the production of a range of sound, well-made linen and wool textiles, sometimes fine and sometimes coarse, but mostly of medium weight. The balanced weaves, tabby and $2 / 2$ twill were standard and diamond-patterned $2 / 2$ twill was common. ${ }^{15}$ Linens were mainly made with $\mathrm{Z}$-spun yarn in warp and weft (ZZ). Most $5^{\text {th }}$-century wool twills were also spun ZZ, but in the $6^{\text {th }}$ century there was a shift to ZS spin in wool, a feature which continued for the rest of the Anglo-Saxon period. Many of the textiles in graves represent clothing fabrics, but blankets, coverlets and even mattress covers were included, as well as coarse wrappers for weaponry. These textiles were all well within the capacity of the farmstead weavers, working with the warp-weighted loom.

There are some signs of regional variation in the textile types recovered in smaller numbers. $2 / 1$ twill, soft-finished textiles and tubular selvedges, for example, occur together in certain areas, such as central Norfolk and the Avon valley in Warwickshire. ${ }^{16}$ The $2 / 1$ weave structure is commonly associated with the two-beam vertical loom, which was the main cloth loom of Late Roman Britain, and soft-finishing and tubular selvedges are also regarded as Roman-derived techniques. ${ }^{17}$ Together, they suggest that, in some locations, the incoming Germanic textile culture did not entirely eradicate that of the Romano-British. Those tablet weaves that were patterned also form regional specialities, some of which reflect the heritage of the migrants. ${ }^{18}$ In Kent, the gold thread from gold-brocaded bands must derive from East Kent's connections with the near Continent, but some double-faced repp-effect patterned bands are more likely to represent the region's Jutish inheritance. ${ }^{19}$ Another distinctive technique, with panels of weft-wrapping worked in horsehair, which has been found in Yorkshire and East Anglia, originated in Scandinavia. ${ }^{20}$ Double-faced 3/1 twill tablet-weaving in the same region may also be of Scandinavian ancestry. ${ }^{21}$

If any of the plainer types of textile were ever exchanged, they would be difficult to track archaeologically. The wool

\footnotetext{
${ }^{14}$ Gräslund 2001, 84, 92, 99; Stalsberg 2001, 75-76.

${ }^{15}$ Walton Rogers 2007a, 49-110.

${ }^{16}$ Walton Rogers 2007a, 230-232.

${ }^{17}$ Wild 2002, 20-22.

${ }^{18}$ Walton Rogers 2007a, 89-97.

${ }^{19}$ Walton Rogers 2012, 198-201.

${ }^{20}$ Nockert 1991, 83-89, 96-105.

${ }^{21}$ Walton Rogers 2007a, 92-93.
}

2/2 diamond twills with a common Continental pattern repeat of $20 \times 18$ threads per diamond might represent traded goods, or they might result from Anglo-Saxon adoption of a Continental practice. ${ }^{22}$ A small number of specialist items, however, offer better candidates for goods of exchange. Some fine net-like textiles, made of specially prepared white wool, dyed dark colours and used for veils, scarves and sashes, represent a distinctive and comparatively rare textile type: this is also encountered on the Continent, although there is as yet no clear indication for its place of origin. ${ }^{23}$ Some patterned linens likely to be of Alamannic origin have also been recorded in southerly Anglo-Saxon sites. ${ }^{24}$

More exotic goods are represented by the ivory rings which formed the mouths of bags carried at the hip by women. ${ }^{25}$ An example preserved with remains of a leather cover and a lining made of a form of tapestry-weave foreign to Anglo-Saxon England, has been found in a $6^{\text {th }}$-century grave at West Heslerton, North Yorkshire. ${ }^{26}$ This suggests that whole bags were imported, not just the ivory rings, although the distribution of the finds does not suggest any particular inland trade route. ${ }^{27}$ Similarly, some coverlet weaves in the reversible 3/1 structure known as 'summer-and-winter', likely to have originated in Syria, have been recorded in widely separated sites. ${ }^{28}$ Overseas trade in general seems to have reached northern Europe via two main arteries, one bringing Byzantine goods through the Mediterranean and up the Atlantic coast and the other from North Africa through Italy and into the Frankish world. ${ }^{29}$ If this is correct, then the coverlets will have come via the Atlantic. The route through Italy is more likely to have brought silks into Frankish northern Europe, although silk was still extremely rare in England in the earliest phase.

To summarise, the evidence from the $5^{\text {th }}$ and $6^{\text {th }}$ centuries indicates that most farming households were producing their own cloth, using raw materials raised on their own land or collected in the wild. Most stages of production would be under the control of the women of the household and directed by the farm matron. The same range of textiles is found in site after site across the country, although there were some more localised techniques in, for example, tablet-weaving. The opportunity for trade was probably slight, but a small number of exotic goods appear to have been entering the country. In the absence of any clear internal trade routes, it seems likely that the more valuable items were distributed by gift exchange. Lesser goods, along with lightweight items such as amber and glass beads, might have been distributed by the kind of opportunistic trade where they would pass from hand to hand in an erratic fashion before reaching the point at which they were buried.

\footnotetext{
${ }^{22}$ Bender Jørgensen 1992, 143; Walton Rogers 2007a, 77, 237-238.

${ }^{23}$ Walton Rogers 2007a, 68-69.

${ }^{24}$ Walton Rogers 2007a, 236.

${ }^{25}$ Hills 2001.

${ }^{26}$ Walton Rogers 1999a, 147, 157.

${ }^{27}$ Hills 2001, 143.

${ }^{28}$ Walton Rogers 2007a, 80-82, 236.

${ }^{29}$ Harris 2003, 52-72, 144-152, 176-177.
} 
The $7^{\text {th }}$ and $8^{\text {th }}$ centuries: clothing a social hierarchy

Analysis of the social status of the people buried in the cemeteries indicates that, in the $5^{\text {th }}$ and $6^{\text {th }}$ centuries, there were senior and junior members of the household within each family group, but each community had a roughly similar structure and status to the others. ${ }^{30}$ This began to change from the late $6^{\text {th }}$ century onwards, when high-status graves under burial mounds started to appear in locations separate from the flat cemeteries. Regnal lists and genealogies written in the $8^{\text {th }}$ and $9^{\text {th }}$ centuries indicate that this coincided with the rise of regional kingships. ${ }^{31}$ At the same time, there was a change in landholding patterns, as villages such as West Heslerton shrank in size, ${ }^{32}$ while other settlements shifted location. Larger estates began to emerge and sizeable estate centres, likely to have been occupied by local leading families, have been identified archaeologically. ${ }^{33}$ Inland trade networks developed and emporia or 'wics', acting as conduits for overseas trade, appeared in places with access to the North Sea and English Channel. ${ }^{34}$ Although not large enough to be called towns, the wics contained a more substantial population than the hamlets and villages of the earlier phase.

The practice of clothed-and-furnished burial declined during the later $7^{\text {th }}$ century and there are therefore few surviving textiles from the $8^{\text {th }}$ and early $9^{\text {th }}$ century. The $7^{\text {th }}$-century collections, however, show that changes were taking place. The main weave structures remained as before, but there was now greater standardisation in clothing fabrics, with ZS 2/2 twill, especially diamond twill, typically being used for wool textiles, and plain ZZ tabby for linens. ${ }^{35}$ Few tablet weaves have survived from this phase, but an example from the royal burial ground at Sutton Hoo suggests a fusion of earlier techniques. ${ }^{36}$ A distinctive fabric-type which first appears in graves of this period is spin-patterned tabby with high thread-counts. This textile type has its greatest concentration in Alamannic southern Germany, but its export can be traced along the River Rhine into the Netherlands ${ }^{37}$ and eventually England. ${ }^{38}$

Although the spin-patterned textiles occur in graves of both sexes, there is, overall, a shift in valuable textiles into men's graves. In $5^{\text {th }}$ - and $6^{\text {th }}$-century cemeteries, there is a strong sense of 'equal but different' between the two genders, but this changes in the $7^{\text {th }}$ century. ${ }^{39}$ Gold thread, for example, disappears from women's graves in Kent and re-appears in two princely male burials. The coverlets or rugs that had been present in $6^{\text {th }}$-century burials, by the

\footnotetext{
${ }^{30}$ Scull 1993, 72-73; Härke 1997, 140-146.

${ }^{31}$ Dumville 1977.

${ }^{32}$ Tipper 2004, 54-55.

${ }^{33}$ Loveluck 2007; Tester et al. 2014.

${ }^{34}$ Naylor 2004, 122-134.

${ }^{35}$ Walton Roger 2007a, 106-107.

${ }^{36}$ Walton Rogers 2005a, 263-266.

${ }^{37}$ Bender Jørgensen 1992, 70, 73-74, 137-138.

${ }^{38}$ Walton Rogers 2007a, 25-26.

${ }^{39}$ Walton Rogers 2007a, 240-241.
}

late $6^{\text {th }}$ and $7^{\text {th }}$ century had become an exclusively male accessory. To the list of valuable goods can be added the figured silks that are known to have been introduced by the Church at this time. In the $8^{\text {th }}$ century, Bede recorded that Abbot Benedict had paid for three hides of land with two lengths of silk, which he had brought back from Rome, ${ }^{40}$ and when the motifs of Byzantine silks transferred into Anglo-Saxon art, it appears to have been through the medium of church vestments and furnishings. ${ }^{41}$ Embroidery and tablet-weaving in dyed silks and spun-gold thread, were also established in England as high-status crafts by the end of the $8^{\text {th }}$ century. ${ }^{42}$

When textiles disappear from the cemeteries, the archaeological evidence for textile-making equipment takes up the story. Finds from two sizeable rural estate centres, at Flixborough in Lincolnshire ${ }^{43}$ and Brandon in Suffolk, ${ }^{44}$ have been studied in depth. At Flixborough, the textile tools from the mid $8^{\text {th }}$ to mid $9^{\text {th }}$ century were consistently small and light. The stone spindle whorls were mostly 10-20 g in weight, loom weights were 120-350 g with a cluster around $200 \mathrm{~g}$ and bone pin-beaters were unusually slender. In addition, the whorls were lathe-turned and more uniform in shape than elsewhere, while a series of stamped marks were recorded on over sixty of the loom weights (Fig. 4). Taken together, this suggests not only the production of fine fabrics, perhaps with an emphasis on linen, but that textiles were being made in a more controlled environment than formerly. There are no Anglo-Saxon written sources concerning textile crafts in this period, but documents from the Continent relating to royal and monastic estates indicate that there were weaving workshops or gynaecea staffed by women, some of whom were slaves and whose workrooms might be 'locked' or 'unlocked'. ${ }^{45}$ No specific workshop was identified at Flixborough, since much of the material came from dumps in the centre of the complex, but the character of the artefacts suggests a greater degree of regulation than can be seen in the farmsteads.

At Brandon there was again an emphasis on lightweight spindle whorls, loom weights and pin-beaters, but with heavier ones alongside. There was also substantial evidence for flax-working and dyeing in the form of dyeplants, Reseda luteola L, and Galium sp, and dye-stained potsherds (see below). Single-ended pin-beaters were recorded, which implies the use of the two-beam vertical loom alongside the warp-weighted. It has already been noted that this loom was probably used for the production of 2/1 twills, but it would also be suitable for tapestry-woven hangings, rugs and coverlets. ${ }^{46}$

\footnotetext{
${ }^{40}$ Bede - Giles (trans.) 1910, Chapter 9.

${ }^{41}$ Webster 2012, 113.

${ }^{42}$ Budny and Tweddle 1985, 361-366, 384-385; Coatsworth 2012, 191-192.

${ }^{43}$ Walton Rogers 2007b; Walton Rogers 2009.

${ }^{44}$ Walton Rogers 2014b.

${ }^{45}$ Tipper 2004, 174-175, 190-191; Walton Rogers 2007a, 45-46.

${ }^{46}$ Wild 1970, 69-72; Walton Rogers 2001, 160-161, 168.
} 


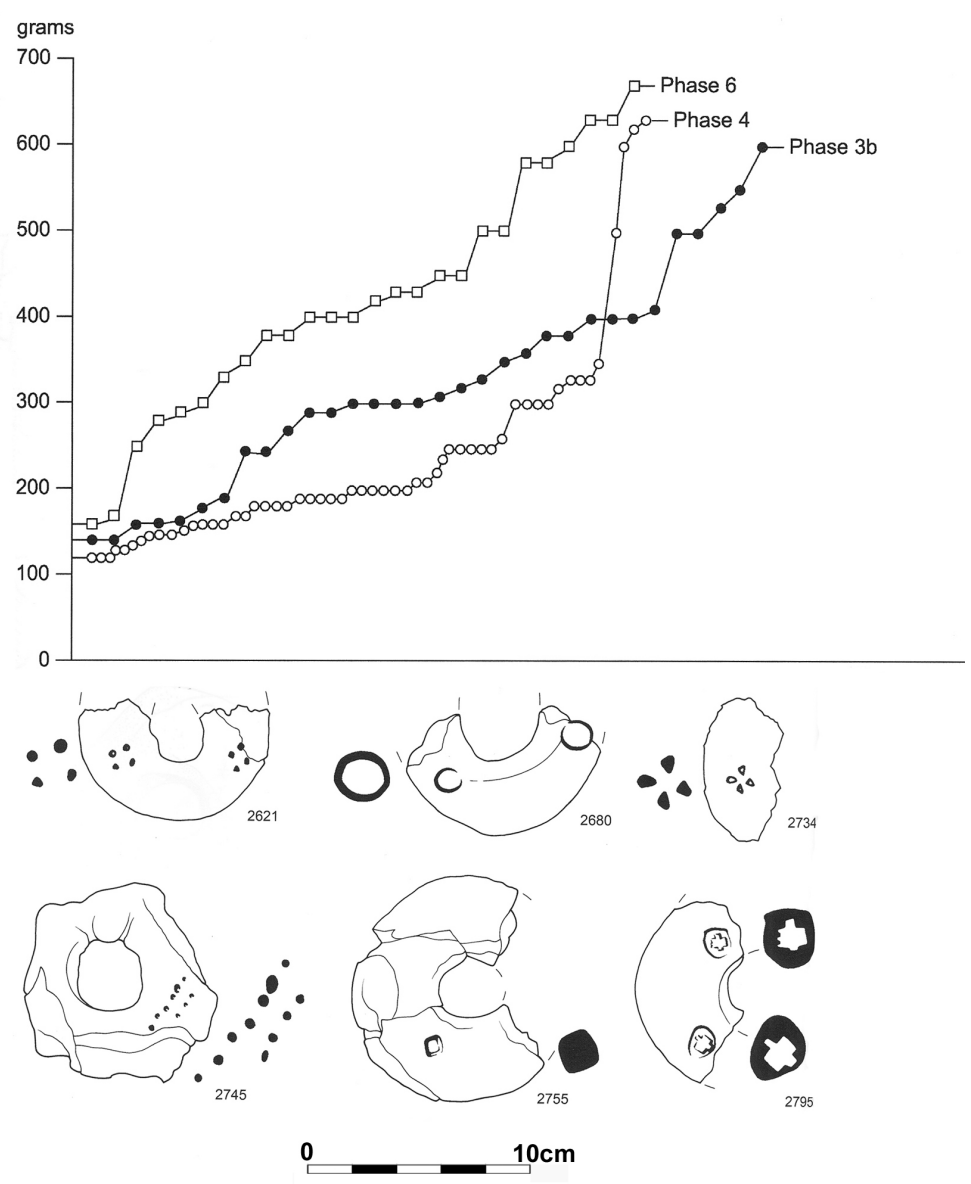

Fig. 4. Loom weights from Flixborough, North Lincolnshire. Above: the light weights from $8^{\text {th }}$ and early $9^{\text {th }}$-century levels (Phases $3 \mathrm{~b}$ and 4) compared with the heavier $10^{\text {th }}$ - and early $11^{\text {th }}$-century ones (Phase 6). C The Anglo-Saxon Laboratory. Below: small weights with impressed marks. (C) Humber Field Archaeology.

The tools that were used for cloth production in the early farmsteads continued in use in the wics. The raw materials must have been brought in from farms outside the settled areas and it has been argued from the evidence of sheep bones that Brandon and estates like it were giving especial attention to wool production at this time. ${ }^{47}$ Their surplus, therefore, could have been sent to the wics to feed the looms there. ${ }^{48}$ The numbers of loom weights recovered do not suggest any intensification of production in the wics. There are difficulties with inter-site comparisons, since there is no standard way of reporting loom weights (by weight, number of fragments or number of complete loom weights) but there appear to be fewer than 80 loom weights (counting those that are $50-100 \%$ complete) from all the Lundenwic sites, even though they cover nearly two centuries of occupation. ${ }^{49}$ This is substantially less than in the early villages and the estate centre at Flixborough. Their weights mostly lie in the

${ }^{47}$ Crabtree 1994; Crabtree 1996, 45-46; Crabtree and Campana 2014, 300-303.

${ }^{48}$ There is little evidence that wool production had reached a level where raw wool would be a significant export: Tipper 2004, 177-182.

${ }^{49}$ Reviewed in Walton Rogers, forthcoming. middle-to-heavy range, which suggest the production of ordinary fabrics. There is also some limited evidence for the two-beam loom at Lundenwic, in the form of a fragment of a toothed weft-beater. ${ }^{50}$ Altogether, the evidence from the wics suggests a household-by-household support industry rather than anything geared towards trade.

This does not mean that textiles did not pass through the wics as a trade commodity. If any surplus was generated by workshops in estate centres such as Flixborough or Brandon, then trade through the nearest market or wic would seem likely. There are parallels for this in early medieval monastic houses of the Continent, where surplus materials would be sold on. ${ }^{51}$ A letter in which Charlemagne asked Offa, King of Mercia, 'that with regard to the length of cloaks, you may order them to be as they used to come to us in old times ${ }^{52}$ also seems to describe a certain level of exchange between $8^{\text {th }}$-century royal courts which could have been channelled through the wics. Other textiles could have come in the opposite direction. Frisians, for example, were the purveyors of wares variously described as coloured cloaks, short striped

\footnotetext{
${ }^{50}$ Cowie et al. 2012, 157.

${ }^{51}$ Pounds 1973, 213-214, 285.

${ }^{52}$ Translated from Haddan and Stubbs 1878, III, 495-498.
} 


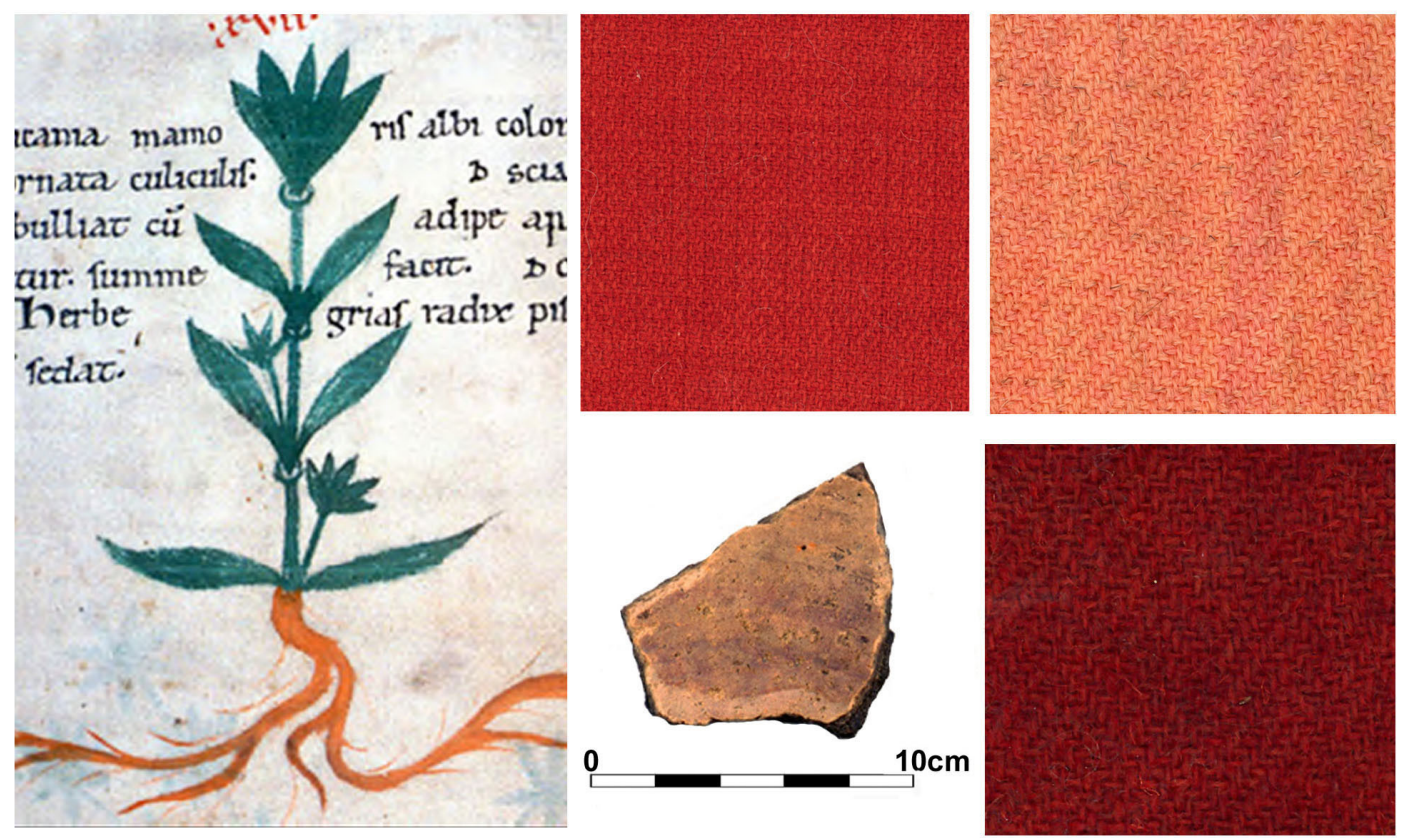

Fig. 5. Anglo-Saxon madder. Left, an illustration of the madder plant from a Late Anglo-Saxon copy of The Herbal of Apuleius Barbarus, MS Bodley 130, fol. 9, reproduced with permission from The Bodleian Libraries, The University of Oxford. Right and centre, swatches replicating textiles dyed with madder excavated at Coppergate, York. Centre, a madder-stained potsherd from Late Anglo-Saxon London. (C) The Anglo-Saxon Laboratory.

Gallic cloaks or simply 'Frisian cloth', and one of their number was present in London in the $7^{\text {th }}$ century ${ }^{53}$ while there were others in York in the $8^{\text {th }}$ century ${ }^{54}$ - although the identity of Frisian cloth in the archaeological record is still debated..$^{55}$

Another commodity that must reflect improving trade conditions is the red dyestuff derived from dyers' madder, Rubia tinctorum L. The roots of this plant have more dye content than the wild species, but it is not native to Britain and it must have been cultivated as an introduced species or imported as a dyestuff (Fig. 5). Red and purple were colours associated with royalty and the earliest example of $R$. tinctorum detected so far was in a fine wool diamond twill from the ship burial at Sutton Hoo. ${ }^{56}$ It was then detected in an $8^{\text {th }}$-century jar from Canterbury ${ }^{57}$ and on the potsherds from Brandon described above. Examples as early as the $7^{\text {th }}$ century have been identified in high-status sites in Ireland and Scotland, on the inner face of imported Continental E-ware pottery. ${ }^{58}$ Since madder was cultivated on the imperial estates in Charlemagne's empire, ${ }^{59}$ it seems likely that pots and madder arrived together in the Irish Sea network.

\footnotetext{
${ }^{53}$ Bede, Historia Ecclesisastica IV, 22.

${ }^{54}$ Altfrid, Vita Liudgeri, I, 11-12.

${ }^{55}$ Ingstad 1979; Bender Jørgensen 1992, 140-143; Hägg 1994.

${ }^{56}$ Whiting 1983.

${ }^{57}$ Walton Rogers 1999b.

${ }^{58}$ Walton Rogers 2005b; Campbell 2007, 32-50, 80.

${ }^{59}$ Capitulare de Villis vel Curtis, no.70: Loyn and Percival
} 1975, 73 .
To sum up, the $7^{\text {th }}$ and $8^{\text {th }}$ centuries saw the rise of kingships and aristocratic households, which would require substantial quantities of different sorts of cloth to support their lifestyle. These textiles are likely to have been produced in controlled workshops in estate centres. The Christian Church was bringing in exotic silks for vestments and hangings and there are signs of a developing trade in dyestuffs, and in cloth carried by Frisian merchants. We can also see the beginnings of a supply network to feed essential raw materials to households in centres of population. This is something which develops further in the next phase.

\section{The $9^{\text {th }}$ to $11^{\text {th }}$ centuries: urban cloth production}

During the $9^{\text {th }}$ century, the activity of the wics often appears to have relocated to nearby sites and to have changed in character. They, and other new centres of population, increased in size and became the focus for civic activities such as the administration of justice, as well as commerce. ${ }^{60}$ Textile crafts played a prominent role in these newly emergent towns. The archaeological evidence from York and Winchester has been studied in depth and there is significant supplementary information from Lincoln, Thetford and London. ${ }^{61}$

If the start of urbanisation is regarded as the mid- $9^{\text {th }}$ century, then for the first fifty years or so, cloth was produced in towns with the same equipment as formerly. Around

${ }^{60}$ Scull 1997, 274.

${ }^{61}$ Mann 1982; Pritchard 1984; Rogerson and Dallas 1984; Walton 1989; Biddle 1990; Pritchard 1991; Walton Rogers 1997. 

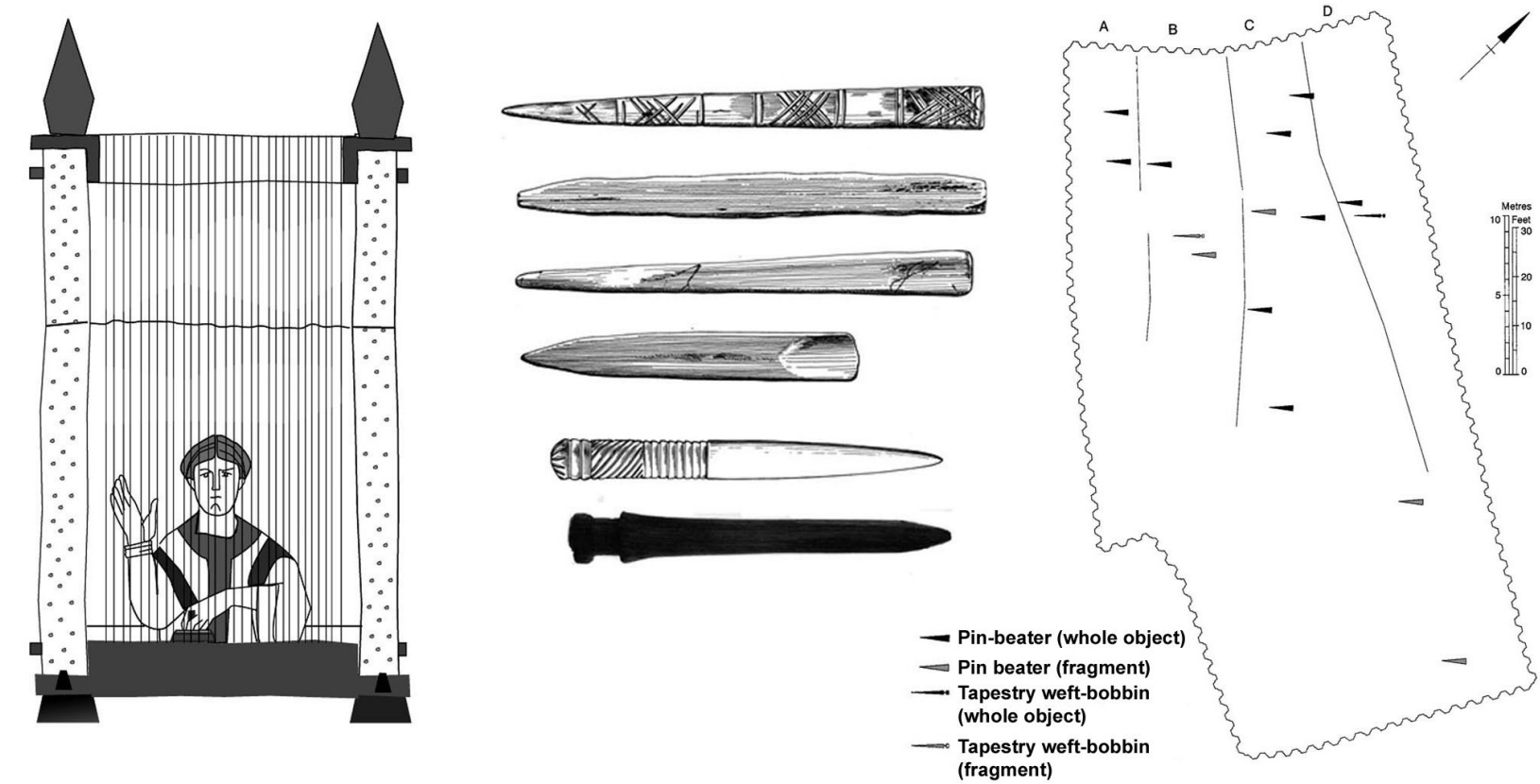

Fig. 6. The two-beam vertical loom. Left, re-drawn copy of an illustration from De Rerum Naturis by Hrabanus Maurus, AD 1022-1025, based on Library of Monte Casino MS 132 fol. 364. Centre, single-ended pin-beaters and possible tapestry bobbins from Coppergate, York. Right, the four excavated tenements at Coppergate, showing the find location of single-ended pin-beaters and tapestry bobbins. The built area giving onto the street frontage is in the top one-third of the plan and the backyard area leading to the river at the bottom. (C) The Anglo-Saxon Laboratory.

the turn of the century, however, there was a major technological shift in towns, as loom weights, weaving battens and cigar-shaped pin beaters disappeared and were rapidly replaced by single-ended pin-beaters. ${ }^{62}$ This has been interpreted as the arrival of the two-beam vertical loom as a cloth loom (Fig. 6), and it correlates with an increase in 2/1 twill structures in $10^{\text {th }}$ - and $11^{\text {th }}$-century textile collections.

Although the loom may have changed, the organisation of textile production seems to have been similar to that seen in the earlier sites. At Coppergate, York, a row of four tenements with good stratigraphy stretching from the mid $9^{\text {th }}$ to the $11^{\text {th }}$ centuries was excavated on a main thoroughfare in the busiest part of the town (Fig. 6).${ }^{63}$ Here flax processing was carried out in the back yards, well away from the buildings, while spinning and weaving was focused on the structures at the street end of the plot. These tenements have been interpreted as the homes and workshops of artisans who specialised in individual crafts, and whose tools and waste were found concentrated in different buildings at different times. Since the evidence for textile production was spread across all the tenements, it has been interpreted as a domestic support industry, as it was in the wics. On the other hand, a careful comparison with the material from contexts of similar date, size and location at a nearby site in Pavement, found that the Coppergate tenements had produced a greater

\footnotetext{
${ }^{62}$ Walton Rogers 2001.

${ }^{63}$ Walton Rogers 1997.
}

volume of evidence. ${ }^{64}$ More studies are required of sites of this nature, but if the extra quantity of material from Coppergate genuinely reflects a higher level of production, then it suggests that some domestic weavers were producing extra cloth, perhaps for sale at local markets.

Dyestuffs, particularly dyers' madder, become much more prominent in the archaeological record at this stage (Fig. 5). In York, remains of dyers' madder, R. tinctorum, woad, I. tinctoria, dyers' greenweed, G. tinctoria, and weld, $R$. luteola, together with an imported clubmoss, Diphasium complanatum (L) Rothm (for use as a mordant), were recovered in quantity at several sites, and at Coppergate the ground next to one of the tenement buildings was found to be still stained red with the waste from a $10^{\text {th }}$-century dyebath. ${ }^{65}$ At London, Thetford and Winchester, red-stained potsherds have been recovered, and, where analysed, these have proved to be the remains of madder dye-pots. ${ }^{66}$ Written sources of the $11^{\text {th }}$ century, such as the estate memorandum known as be gesceadwisan gerefan ('the good reeve') indicate that madder was by now being cultivated in England ${ }^{67}$ and a poem by Winric of Trèves (Trier) recognises red dyes as the speciality of Britain (Conflictus Ovis et Lini, 215-38). Madder has certainly been much more commonly identified in Late

${ }^{64}$ Walton Rogers 1997, 1825.

${ }^{65}$ Cf. Hall in: Walton Rogers 1997, 1767-1769.

${ }^{66}$ Pritchard 1991, 168-170; Walton Rogers 1996b; Walton Rogers 1997, 1769; Teague 2011, 203-206.

${ }^{67}$ Liebermann 1903, 454. 
Anglo-Saxon textiles than in those from Ireland or Scandinavia. ${ }^{6}$ At Winchester, the dye-pots were recovered in quantity from a number of sites in the workshop area of the town, from levels dated to the later $9^{\text {th }}$ to $11^{\text {th }}$ centuries. ${ }^{69}$ The relatively small sizes of dye-pots of this period (rim diameters 200$300 \mathrm{~mm}$ ) mean the dye must have been applied to raw wool or by the hank and the broad distribution of the evidence suggests numerous small-scale dyers. This can be interpreted as an intermediate phase, at the interface between domestic production and the specialist dye workshops of later centuries. ${ }^{70}$

The towns, like the wics, must have been obtaining much of their raw materials (wool, flax, hemp and dyestuffs) from farms and estates outside the town, which begs the question, what was happening to rural production? Outside the towns, the warp-weighted loom continued in use for at least another century. At Sparkford, a hamlet outside medieval Winchester, for example, a Saxo-Norman building burned down with two sets of weights inside. ${ }^{71}$ At Flixborough also, loom weights continued to be recovered from $10^{\text {th }}$-century and later levels, although by now they had returned to standard sizes, 250-650 $\mathrm{g}^{72}$ (Fig. 4). If it is accepted that $2 / 1$ twills represent the two-beam vertical loom used in towns, and $2 / 2$ twills the warp-weighted loom of the countryside, the presence of both weave structures, side-by-side in $10^{\text {th }}$-century collections in York and Winchester, must suggest that the products of the country looms were being brought into the town. Amongst the ZS 2/2 diamond twills found in York excavations there are six examples of an unusually small pattern repeat, with antecedents in the county, which suggests a regional supply network. ${ }^{73}$

Overseas trade networks continued to develop in the Late Anglo-Saxon period. In Ælfric of Eynsham's Colloquy, the goods ascribed to the merchant included purpuram et sericum... uarias uestes et pigmenta (lines 159-16174). 'purpura and silk... divers garments and dyes' (purpura was a valuable silk with the extended meaning of 'finery'). Churchmen continued to bring back silks from pilgrimages, while the arrival of Scandinavians in northern England brought access to the immense trade networks of the Viking world..$^{75}$ Plain silks and silk ribbons recovered from York must owe their presence to these networks, which linked Britain via the Baltic Sea and Russian rivers to Byzantium and the Silk Road. ${ }^{76}$ The existence in York of an unused silk offcut together with finished silk coifs with the same structural characteristics suggests that bolts of silk were being cut up and made into wearable goods within the town, while a coif with identical features found in Lincoln, $110 \mathrm{~km}$ to the south, implies the

\footnotetext{
${ }^{68}$ Walton 1988.

${ }^{69}$ Teague 2011.

${ }^{70}$ Salzman 1923, 208-214; Walton 1991, 336-337.

${ }^{71}$ Collis 1978; Keene 1990, 203-208.

${ }^{72}$ Walton Rogers 2009, 293-296.

${ }^{73}$ Walton Rogers, forthcoming.

${ }^{74}$ Garmonsway (trans.) 1967.

${ }^{75}$ Walton Rogers, forthcoming.

${ }^{76}$ Walton 1989, 419-420.
}

movement of such goods to other towns. Together with the imported clubmoss used as a dye, these suggest that certain parts of the textile industry had changed gear and become more than just a local support industry.

\section{Conclusion}

There are many areas of this study that require more data collection from future excavations, but the following conclusions have been drawn from the evidence as it stands at present. In the $5^{\text {th }}$ and $6^{\text {th }}$ centuries, making textiles with locally available materials was an essential activity for each individual farming household. It seems to have been carried out mainly by the women of the household under the direction of the farm matron. As large estate centres developed in the $7^{\text {th }}$ and $8^{\text {th }}$ centuries, estate workshops began to focus on the production of quality textiles to support the rising elite and these workshops are likely to have been more closely controlled than previously. Some of the women who worked there could have been non-free and, certainly, by the time that written sources become more common in the Late Anglo-Saxon period, a woman-weaver and a seamstress appear as slaves. ${ }^{77}$ In trading centres, as in later towns, however, the archaeological evidence suggests that textile manufacture was still for many people a household-based craft. The difference was that women in these more populous centres would now have to draw on raw materials brought in from outside - which represents a major shift from the self-sufficiency of the farms. The $10^{\text {th }}$-century arrival of a new loom that could be easily managed by one person, may also have suited an urban weaver working with fewer helpers than a farm could provide.

The period in question witnessed a gradual improvement in trading conditions. A small number of exotic goods appear to have been entering the country in the $5^{\text {th }}$ and $6^{\text {th }}$ centuries, but this was given extra impetus by the need of kings, aristocratic households and the Christian Church for prestigious garments and hangings. Reds and purples were always in demand in royal courts and, since dyestuffs were lightweight commodities which could be transported for profit over long distances, it is perhaps not surprising to find early evidence for a trade in red madder dye. At the same time, as trading centres started to appear, regional networks to supply the centres of population also began to form.

The textile industry that moved into towns in the $9^{\text {th }}$ century still retained many of the characteristics of a household-run domestic craft (or rather series of crafts), but there are several indications that trade was beginning to play a more significant role than formerly. In York, if not elsewhere, finished cloths as well as raw materials appear to have been drawn into the town from the hinterland, at the same time as clubmoss dye-mordant and bolts of silk were introduced from overseas. There was also an intensification of dyeing as

\footnotetext{
${ }^{77}$ Whitelock 1930, 10-11
} 
a craft, as Britain acquired a reputation on the Continent for its red-dyed wool textiles. Altogether, this suggests a transitional phase, as textile production in towns moved away from domestic production towards the $12^{\text {th }}$-century craft gilds and the manufacture of goods for sale. It is likely that there was a gender shift at this stage, as the ground was laid for the rise of the male clothier of later centuries. The period as a whole can therefore be seen as the root and foundation from which the later medieval cloth industry would emerge.

\section{Sources}

Ælfric. Colloquy. G. N. Garmonsway (ed. and trans.). Ælfric’s Colloquy. London 1967.

Altfrid. Vita Liudgeri, I, 11-12. D. Whitelock (ed. and trans.). English Historical Documents 1, c. 500-1042. London 1955.

Bede. Vita Abbatum Wiremuthensium et Girvensium. J. A. Giles (ed. and trans.). Lives of the Abbots of Wearmouth and Jarrow. London 1910.

Bede. Historia Ecclesiastica. B. Cosgrave, R. A. B. Mynors (eds. and trans.). Bede's Ecclesiastical History of the English People. Oxford 1969.

\section{Bibliography}

Bender Jørgensen L. 1992. North European Textiles until AD 1000. Aarhus.

Biddle M. 1990. Object and Economy in Medieval Winchester. Winchester Studies 7 (1). Oxford.

Budny M., Tweddle D. 1985. The Early Medieval Textiles at Maaseik, Belgium. “Antiquaries Journal” 65 (2), $353-389$.

Campbell E. 2007. Continental and Mediterranean Imports to Atlantic Britain and Ireland, AD 400-800. CBA Research Report 157 . York.

Chester-Kadwell M. 2009. Early Anglo-Saxon Communities in the Landscape of Norfolk. British Archaeological Reports. British Series 481. Oxford.

Coatsworth E. 2012. Embroideries: Ante-1100. In: G. R. Owen-Crocker, E. Coatsworth, M. Hayward (eds.), Encyclopedia of Dress and Textiles in the British Isles c. 450-1450. Leiden, Boston, 190-195.

Collis J. 1978. Back Street, St Cross. Winchester Excavations III (1949-60) 2, 33-39.

Cowie R., Blackmore L., Davis A., Keily J., Rielly K. 2012. Lundenwic: Excavations in Middle Saxon London 1987-2000. Museum of London Archaeology Monograph 63. London.

Crabtree P. 1990. West Stow: Early Anglo-Saxon Animal Husbandry. East Anglian Archaeology 47. Ipswich.

Crabtree P. 1996. Production and Consumption in an Early Complex Society: Animal Use in Middle Saxon East Anglia. "World Archaeology" 28 (1), 58-75.

Crabtree P., Campana D. 2014. Animal Bone. In: A. Tester, S. Anderson, I. Riddler, R. Carr, Staunch Meadow, Brandon, Suffolk: A High Status Middle Saxon Settlement on the Fen Edge. East Anglian Archaeology 151. Bury St Edmunds, $296-313$.

Dumville D. 1977. Kingship, Genealogies and Regnal Lists. In: P. Sawyer, I. Wood (eds.), Early Medieval Kingship. Leeds, 72-104.

Gräslund A.-S. 2001. The Position of Iron Age Scandinavian Women: Evidence from Graves and Rune Stones. In: B. Arnold, N. L. Wicker (eds.), Gender and the Archaeology of Death. Lanham (US), 81-102.

Haddan A. W., Stubbs W. 1869-1878. Councils and Ecclesiastical Documents relating to Great Britain and Ireland (3 vols).

Hägg I. 1994. Friesisches Tuch. In: G. Jaacks, K. Titow (eds.), Archäologische Textilfunde. Archaeological Textiles: Textilsymposium Neumünster 4.-7.5. 1993. North European Symposium for Archaeological Textiles V. Neumünster, 82-108.

Hamerow H. 1993. Excavations at Mucking Volume 2: The Anglo-Saxon Settlement (Excavations by M. U. Jones and W. T. Jones). English Heritage Archaeological Report 21. London.

Härke H. 1997. Early Anglo-Saxon Social Structure. In: J. Hines (ed.), The Anglo-Saxons from the Migration Period to the Eighth Century: An Ethnographic Perspective. Woodbridge, 125-170.

Harris A. 2003. Byzantium, Britain and the West: The Archaeology of Cultural Identity AD 400-650. Stroud (UK).

Higham N. J. 1992. Rome, Britain and the Anglo-Saxons. London.

Hills C. 2001. From Isidore to Isotopes: Ivory Rings in Early Medieval Graves. In: H. Hamerow, A. MacGregor (eds.), Image and Power in the Archaeology of Early Medieval Britain: Essays in Honour of Rosemary Cramp. Oxford, 131-146.

Hills C. 2003. Origins of the English. London.

Ingstad A. S. 1979. Frisisk klede? En diskusjon omkring noen fine tekstiler fra yngre jernalder. "Viking" 43, 81-95.

Keene D. 1990. The Textile Industry. In: M. Biddle, Object and Economy in Medieval Winchester. Winchester Studies 7 (1). Oxford, 200-208. 
Leslie S., Winney B., Hellenthal G., Davison D., Boumertit A., Day T., Hutnik K., Royrvik E. C., Cunliffe B. 2015. The FineScale Genetic Structure of the British Population. "Nature" 519 (March), 309-314 and supplementary pages.

Liebermann F. 1903. Die Gesetze der Angelsachsen 1: Text und Übersetzung. Tübingen.

Loveluck C. 2007. Rural Settlement Lifestyles and Social Change in the First Millennium AD: Anglo-Saxon Flixborough in Its Wider Context. Excavations at Flixborough 4. Oxford.

Loyn H. R., Percival J. 1975. The Reign of Charlemagne: Documents on Carolingian Government and Administration. Documents of Medieval History 2. New York.

Mann J. 1982. Early Medieval Finds from Flaxengate. The Archaeology of Lincoln 14 (1). London.

Naylor J. 2004. An Archaeology of Trade in Middle Saxon England. British Archaeological Reports. British Series 376. Oxford.

Nockert M. 1991. The Högom Find and Other Migration Period Textiles and Costumes in Scandinavia. Archaeology and Environment 9: Högom II. Umeå.

Pounds N. J. G. 1973. An Historical Geography of Europe 450 BC-AD 1330. Cambridge.

Pritchard F. 1984. Late Saxon Textiles from the City of London. "Medieval Archaeology" 28, 46-76.

Pritchard F. 1991. Small Finds. In: A. G. Vince (ed.), Aspects of Saxo-Norman London 2. Finds and Environmental Evidence. London, 120-278.

Rogerson A., Dallas C. 1984. Excavations in Thetford, 1948-59 and 1973-80. East Anglian Archaeology Report 22. Gressenhall. Salzman L. F. 1923. English Industries of the Middle Ages. Oxford.

Scull C. J. 1993. Archaeology. Early Anglo-Saxon Society and the Origins of Anglo-Saxon Kingdoms. "Anglo-Saxon Studies in Archaeology and History" 6, 65-82.

Scull C. J. 1997. Urban Centres in Pre-Viking England? In: J. Hines (ed.), The Anglo-Saxons from the Migration Period to the Eighth Century: An Ethnographic Perspective. Woodbridge, 269-310.

Stalsberg A. 2001. Visible Women Made Invisible: Interpreting Varangian Women in Old Russia. In: B. Arnold, N. L. Wicker (eds.), Gender and the Archaeology of Death. Lanham (US), 65-79.

Teague S. 2011. The Anglo-Saxon Burh and the Anglo-Norman and Medieval City: Overview and Discussion. In B. M. Ford and S. Teague, Winchester - a City in the Making. Archaeological Excavations between 2002 and 2007 on the Sites of Northgate House, Staple Gardens and the Former Winchester Library, Jewry Street. Oxford Archaeology Monograph 12, Oxford, 187-224.

Tester A., Anderson S., Riddler I., Carr R. 2014. Staunch Meadow, Brandon, Suffolk: A High Status Middle Saxon Settlement on the Fen Edge. East Anglian Archaeology 151. Bury St Edmunds.

Tipper J. 2004. The Grubenhaus in Anglo-Saxon England: An Analysis and Interpretation of the Evidence from a Most Distinctive Building Type. Yedingham.

Walton P. 1988. Dyes of the Viking Age: A Summary of Recent Work. "Dyes in History and Archaeology" 7, 14-20.

Walton P. 1989. Textiles, Cordage and Raw Fibre from 16-22 Coppergate. The Archaeology of York 17 (5). London.

Walton P. 1991. Textiles. In: J. Blair, N. Ramsay (eds.), English Medieval Industries. London, 319-354.

Walton Rogers P. 1997. Textile Production at 16-22 Coppergate. The Archaeology of York 17 (11). York.

Walton Rogers P. 1999a. The Textiles. In: C. Haughton, D. Powlesland, West Heslerton. The Anglian Cemetery I, The Excavation and Discussion of the Evidence. Yedingham, 143-171.

Walton Rogers P. 1999b. Identification of Dye on Middle Saxon Pottery from Christ Church College, Canterbury's Archaeology 1996-1997. 21 ${ }^{\text {st }}$ Annual Report of Canterbury Archaeological Trust. Canterbury, 36.

Walton Rogers P. 2001. The Re-appearance of an Old Roman Loom in Medieval England. In: P. Walton Rogers, L. Bender Jørgensen, A. Rast-Eicher (eds.), The Roman Textile Industry and Its Influence: A Birthday Tribute to John Peter Wild. Oxford, 158-171.

Walton Rogers P. 2005a. The Textiles from Mounds 5, 7, 14 and 17. In: M. O. H. Carver, Sutton Hoo: A Seventh-Century Princely Burial Ground and Its Context. London, 262-268.

Walton Rogers. P. 2005b. Dyestuff Analysis of E Ware Pottery. In: A. Crone and E. Campbell, A Crannog of the First Millennium AD: Excavations by Jack Scott at Loch Glashan, Argyll, 1960. Edinburgh, 61-62.

Walton Rogers P. 2007a. Cloth and Clothing in Early Anglo-Saxon England (AD 450-700). Council for British Archaeology Research Report 145. York.

Walton Rogers P. 2007b. The Importance and Organisation of Textile Production. In: C. Loveluck, Rural Settlement Lifestyles and Social Change in the First Millennium AD: Anglo-Saxon Flixborough in Its Wider Context. Excavations at Flixborough 4. Oxford, 106-111.

Walton Rogers P. 2009. Textile Production. In: D. H. Evans, C. Loveluck, Life and Economy at Early Medieval Flixborough c. AD 600-1000: The Artefact Evidence. Excavations at Flixborough 2. Oxford, 281-316.

Walton Rogers P. 2012. Costume and Textiles. In: K. Parfitt, T. Anderson, Buckland Anglo-Saxon Cemetery, Dover Excavations 1994. The Archaeology of Canterbury New Series 6. Canterbury, 179-235. 
Walton Rogers P. 2014a. Cloth, Clothing and Anglo-Saxon Women. In: S. Bergerbrant, S. H. Fossøy (eds.), A Stitch in Time: Essays in Honour of Lise Bender Jørgensen. Gotarc series A: Gothenburg Archaeological Studies 4. Gothenburg, 253-280.

Walton Rogers P. 2014b. Textile Production and Treatment. In: A. Tester, S. Anderson, I. Riddler, R. Carr, Staunch Meadow, Brandon, Suffolk: A High Status Middle Saxon Settlement on the Fen Edge. East Anglian Archaeology 151. Bury St Edmunds, 285-294.

Walton Rogers P. forthcoming. Textile Networks in Viking-Age Towns of Britain and Ireland. In: S. Ashby, S. Sindbæk (eds.), Craft Networks in Viking Towns.

Webster L. 2012. Anglo-Saxon Art. London.

West S. 1985. West Stow, The Anglo-Saxon Village. East Anglian Archaeology 24 (2 vols).

Whitelock D. (ed. and trans.). 1930. Anglo-Saxon Wills. Cambridge.

Whiting M. C. 1983. Appendix 2: Dye Analysis. In: R. Bruce-Mitford, The Sutton Hoo Ship Burial 3: Silver, Hanging Bowls, Drinking Vessels, Containers, Musical Instruments, Textiles, Minor Objects. London, 465.

Wild J. P. 1970. Textile Manufacture in the Northern Roman Provinces. Cambridge.

Wild J. P. 2002. The Textile Industries of Roman Britain. "Britannia" 33, 1-41.

Winric of Trèves. Hermanni Contracti Conflictus Ovis et Lini. M. Haupt (ed.). "Zeitschrift für deutsches Altertum” 11 (1859), 215-238.

\section{Streszczenie}

\section{Z farmy do miasta. Zmiany w organizacji produkcji włókienniczej w okresie anglosaskim w Anglii}

Przez znaczną część okresu anglosaskiego (V do XI w. n.e.), produkcja włókiennicza była rzemiosłem organizowanym przy gospodarstwach wiejskich. Jednakże w środkowym okresie anglosaskim, pojawiły się duże posiadłości ziemskie, w których produkowano przeznaczone dla elit dobra o wysokiej jakości oraz niewielkie centra, zajmujące się handlem tkaninami. Powstanie w IX w. miast otworzyło nowe możliwości handlu regionalnego i zamorskiego. W późnym okresie anglosaskim miasta stają się elementem wymiany społecznej i ekonomicznej; powstała też wówczas sieć zapewniająca dopływ surowców. W ten sposób stworzono podstawy dla utworzenia miejskich gildii i dalekosiężnego handlu tekstyliami w Anglii w późniejszych stuleciach. 